\title{
Fragmentation Status of Tall-Tussock Grassland Relicts in the Flooding Pampa, Argentina
}

\author{
Lorena P. Herrera, ${ }^{1}$ Pedro Laterra, ${ }^{2}$ Néstor O. Maceira, ${ }^{3}$ Karina D. Zelaya, ${ }^{4}$ and Gustavo A. Martínez ${ }^{5}$ \\ Authors are ${ }^{1}$ Postdoctoral student and ${ }^{2}$ Associate Professor, Researcher, CONICET, Facultad de Ciencias Agrarias, Universidad Nacional de Mar del \\ Plata, EEA Balcarce, Instituto Nacional de Tecnología Agropecuaria (INTA), 7620 Balcarce, Buenos Aires, Argentina; ${ }^{3}$ Researcher and ${ }^{4}$ Magister student, \\ EEA Balcarce, INTA, 7620 Balcarce, Buenos Aires, Argentina; and ${ }^{5}$ Professor, Centro de Geología de Costas, Facultad de Ciencias Exactas y Naturales, \\ Universidad Nacional de Mar del Plata, Funes 3250, 7600 Mar del Plata, Buenos Aires, Argentina.
}

\begin{abstract}
Since European settlement vast areas of the tall tussock grassland dominated by Paspalum quadrifarium Lam. and Paspalum exaltatum J. Presl ("pajonal" grassland) in the Flooding Pampa of Argentina were converted to croplands and short grasslands. With the use of Landsat satellite images, we analyzed current (1998-2000) cover and spatial integrity of the pajonal community, and compared it with a vegetation map made 50 yr ago (1956-1960). Six categories of land cover were adopted: crops, sown pastures, short grassland, pajonal, wetlands, and anthropogenic areas. With the use of metrics from FRAGSTATS, landscape pattern and composition were analyzed at two scales: 1) regionally, by comparing two edaphic domain areas with relatively low and high restrictions for agriculture (low-restriction domain [LRD] and high-restriction domain [HRD], respectively); and 2) at landscape scale, by comparing ten 22500 -ha randomly selected areas (landscapes) within each edaphic domain. Current relative cover of pajonal grassland (2173600 ha) was $32.5 \%$, and similar values were obtained within each edaphic domain. However, the number of pajonal patches was higher and their mean patch size, the Euclidean nearest-neighbor distance among patches (degree of isolation), and their border regularity were lower in the LRD than in the HRD. At landscape scale, the mean size of pajonal patches diminished with the percent of agricultural land within both edaphic domains. The isolation among pajonal patches increased with percent of agricultural land in the HRD, whereas no relationship between the isolation of pajonal patches and percent of agriculture was found in the LRD. As suggested by comparison with past vegetation, current pajonal status mostly results from replacement of pajonal grassland by short grassland types, cultivated pastures, and annual crops ( $52 \%$ and $44 \%$ of previously occupied areas in LRD and HRD, respectively), but some expansion of pajonal grassland was also observed ( $10 \%$ and $4 \%$ of previously unoccupied areas in LRD and HRD, respectively).
\end{abstract}

\section{Resumen}

Desde el establecimiento europeo grandes áreas del pastizal de pastos altos dominados por Paspalum quadrifarium Lam. y $P$. exaltatum J. Presl ("pajonal") en la Pampa Inundable de Argentina se convirtieron en cultivos y pastizales de pastos cortos. Usando imágenes satelitales Landsat analizamos la cobertura actual (1998-2000) y la integridad espacial de la comunidad de pajonal, y lo comparamos con un mapa de vegetación realizado hace 50 años (1956-1960). Se adoptaron seis categorías de cobertura de la tierra: cultivos, pasturas cultivadas, pastizal corto, pajonal, humedales y áreas antropogénicas. Usando índices de FRAGSTATS, el patrón y la composición del paisaje fueron analizados en dos escalas: 1) regionalmente, comparando dos dominios edáficos con restricciones relativamente bajas y altas para la agricultura (dominio de baja restricción [DBR] y dominio de alta restricción [DAR], respectivamente), y 2) a escala del paisaje, comparando diez áreas (paisajes) de 22 500-ha seleccionadas al azar dentro de cada dominio edáfico. La cobertura relativa actual del pastizal de pajonal (2173600 ha) fue $32.5 \%$ y valores similares fueron obtenidos en cada dominio edáfico. No obstante, el número de parches de pajonal fue mayor y su tamaño de parche promedio, la distancia Euclidiana al vecino más cercano entre parches (grado de aislamiento) y su regularidad de borde fueron menor en el DBR respecto al DAR. A escala del paisaje, el tamaño promedio de parches de pajonal disminuyó con el porcentaje de agricultura dentro de ambos dominios edáfico. El aislamiento entre parches de pajonal aumentó con el porcentaje de agricultura en el DAR, pero no se encontró relación entre el aislamiento de parches de pajonal y el porcentaje de agricultura en el DBR. Tal como se sugirió en comparación con la vegetación pasada, el estado del pajonal actual resulta mayormente del reemplazo del pajonal por tipos de pastizales cortos, pasturas cultivadas y cultivos anuales ( $52 \%$ y $44 \%$ de las áreas previamente ocupadas en el DBR y DAR, respectivamente), pero alguna expansión de pajonal fue observada ( $10 \%$ y $4 \%$ de las áreas previamente desocupadas en el DBR y DAR, respectivamente).

Key Words: Flooding Pampa, FRAGSTATS, Landsat Thematic Mapper, landscape, land-use classification, Paspalum quadrifarium

Research was funded by Agencia Nacional de Promoción Científica y Tecnológica, Universidad Nacional de Mar del Plata, and INTA, Argentina. L.P.H. was supported by a doctoral fellowship from CONICET (Argentina).

This work is part of the thesis submitted by Lorena P. Herrera in fulfillment of the requirement for the "Doctorado en Ciencias Biológicas" of the National University of Mar del Plata (UNMdP).

Correspondence: Lorena P. Herrera, Facultad de Ciencias Agrarias, Universidad Nacional de Mar del Plata, EEA Balcarce, INTA, CC 276, 7620 Balcarce, Buenos Aires, Argentina. Email: |herrera@mdp.edu.ar

Manuscript received 5 February 2008; manuscript accepted 8 October 2008. 


\section{INTRODUCTION}

Landscape changes throughout the world are associated with an increasing rate of fragmentation of natural and seminatural habitats (Eriksson et al. 2002). In fragmented landscapes the conservation of the original biota entirely depends on the retention and management of these remnants (Saunders et al. 1991). However, highly fragmented landscapes pose particularly difficult problems for conservation planning, because remnants of natural habitat are highly vulnerable to a wide array of processes that threaten the long-term maintenance of biodiversity (Saunders et al. 1991; Fahrig and Merriam 1994). The transformation and replacement of natural grasslands affect not only the conservation of this ecosystem and its native biodiversity, but also the maintenance of different ecological services at regional and global levels. These services include the provision of plant genetic resources for forage and industrial utilization, atmospheric carbon sequestration, soil protection, and water flux regulation (Paruelo and Sala 1993; Costanza et al. 1997; Millennium Ecosystem Assessment 2005).

Landscape structure is a result of complex interactions between physical, biological, economic, political, and social driving forces (Apan et al. 2002). Landscape fragmentation is not a random process; clearing of native vegetation may occur in areas where agriculture or intensive cattle raising are economically profitable activities (Kemper et al. 2000). As a consequence, most landscapes have been influenced by human land use, and the resulting landscape mosaic is a mixture of natural and human-managed patches that vary in size, shape, and arrangement (Turner et al. 1989).

Temperate grasslands are one of the least protected biomes of the world (Hoekstra et al. 2005). This is particularly true for the Rio de la Plata Grasslands, in the South Cone of South America, which is composed of the Pampas of Central-East Argentina and the Campos of Uruguay and South of Brazil. Just $0.3 \%$ of the Pampas, $0.2 \%$ of the Uruguayan Campos, and $2.2 \%$ of Rio Grande do Sul grasslands are included within protected areas (Bilenca and Miñarro 2004). In most of these regions, the suitability of soils for crop cultivation has determined the clearance of grasslands over a large proportion of their original area (Guerschman et al. 2003a, 2003b; Paruelo et al. 2004), whereas the remnant grasslands have been largely modified by cattle and sheep grazing (Millot et al. 1987; Rush and Oesterheld 1997; Altesor et al. 1998, 2005; Jaurena and Rivas 2005). At present, these grasslands are being replaced by crop fields, due to the availability of new technologies and market conditions. As a consequence of the expansion of crop frontiers, the displacement to and concentration of livestock in marginal areas for agriculture constitutes an additional threat to the ecological integrity of these highly vulnerable grassland relicts (Ghersa and Ghersa 1991; Pallarés et al. 2005; ManuelNavarrete et al. 2006). As result of both agriculture and forestry expansion, the area of native or modified grasslands was reduced by 980000 ha $(7.7 \%)$ between 1990 and 2000 in Uruguay (Dirección de Estadísticas Agropecuarias 2003), by 1416000 ha (11.9\%) between 1985 and 1995 in Rio Grande do Sul (Instituto Brasileiro de Geografia e Estatística 1999), and by 924000 ha $(3.6 \%)$ between 1988 and 2002 in the Argentine Pampas (Bilenca and Miñarro 2004; Instituto Nacional de Estadística y Censos 2004).

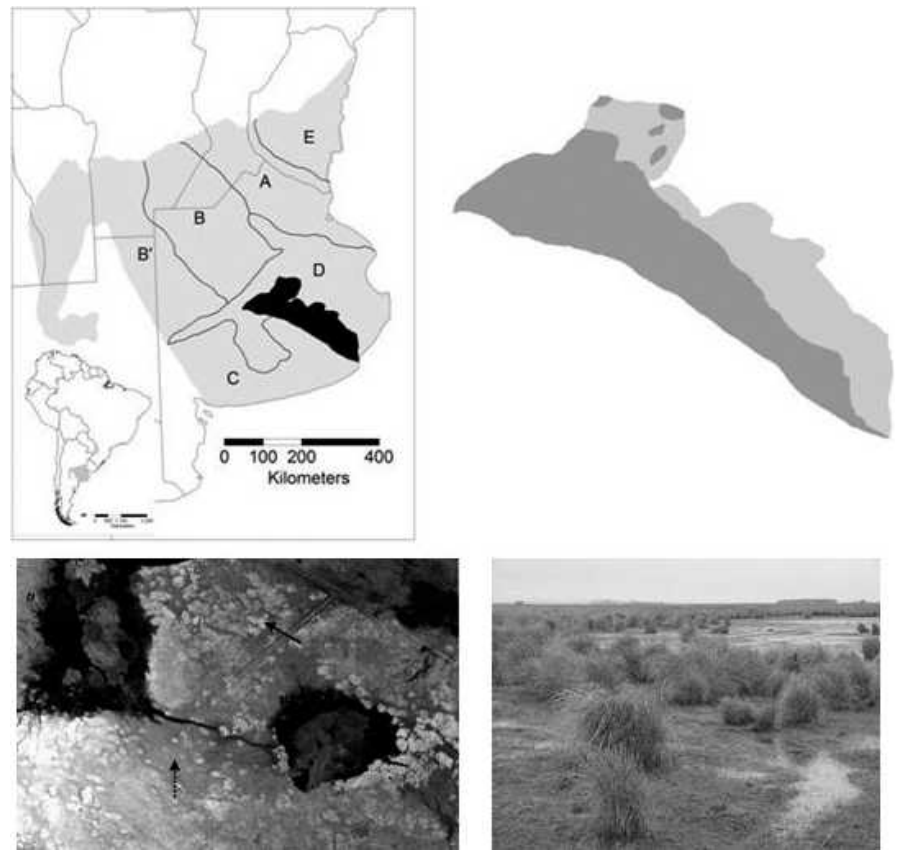

Figure 1. Figure on the upper left shows regional subdivisions of pampa region in Argentina ( $\mathbf{A}$, Rolling Pampa; $\mathbf{B}$, Inland Pampa with two divisions; C, Southern Pampa; D, Flooding Pampa; and E, Mesopotamic Pampa; Soriano et al. 1991); black area represents the study area. An expansion of the study area is on the upper right, where dark gray represents areas dominated by pajonal grasslands, light gray corresponds to the areas of short grasslands, and the pajonal appear as a minor component (Vervoorst 1967). Figure on the lower left shows an aerial photograph of a typical Flooding Pampa landscape; the whole arrow indicates pajonal patches, and the cut arrow indicates short grassland. Figure on the lower right shows a detail of the pajonal-short grassland mosaic.

Paspalum quadrifarium Lam. and Paspalum exaltatum J. Presl (locally known as "paja colorada") are warm-season tussock grasses that form dense and tall tussock grasslands (hereafter, pajonal), and are distributed between lat $30^{\circ} \mathrm{S}$ and lat $39^{\circ} \mathrm{S}$ (Quarín and Lombardo 1986; Alonso et al. 1995). These species are still frequent in the Flooding Pampa (Fig. 1) and in the hills of the Southern Pampa, Argentina (Soriano 1991), and have probably dominated the presettlement vegetation over vast areas of the humid-subhumid pampas before they were replaced by croplands in almost all agricultural soils and by short grasslands in most cattle ranches (Vervoorst 1967; Laterra et al. 1998, 2003). The first floristic and geographic description of Paspalum spp.-dominated grasslands was made between 1956 and 1960 by Vervoorst (1967) within the Salado River Basin (lately included within the Flooding Pampa), who named this tall tussock grassland as Paspaletum. According to Vervoorst (1967), the Paspaletum was more abundant and continues over a wide fringe of approximately 1400000 ha extending from northwest to southeast in the middle south of the Flooding Pampa, and as a minor component toward the north of the mentioned fringe where short grasslands dominate. In the Flooding Pampa the area occupied by pajonal grassland comprises two edaphic domains of Buenos Aires Province, with different edaphic restrictions for agriculture: a low-restriction domain (edaphic 
domain 22) and a high-restriction domain (edaphic domain 23; Instituto Nacional de Estadística y Censos and Secretaria de Agricultura, Ganadería, Pesca y Alimentos [INTA y SAGPyA] 1989). The high-restriction domain presents a continuous calcareous layer at $50-100-\mathrm{cm}$ depth that constrains water drainage and storage and represents a physical barrier for the growth of crop roots.

Because of the low cattle receptivity of mature pajonal, current management of this community is based on periodical or occasional burning, which induces short-term enhancement in quality, productivity, and accessibility of the resprouting forage for cattle, as well as transitional floristic stages characterized by the establishment of different forage and weed species (Laterra et al. 2003). Other disturbances, such as plowing or herbicide spraying (glyphosate), are applied to the pajonal remnants with increasing frequency, aiming at their complete replacement by short grasses or annual crops. Although fire-induced transitional stages of pajonal are reversible, their replacement by short grassland seems to be a nonreversible point (Laterra et al. 1998). Therefore, the area of the pajonal has diminished during the last decades, particularly since the increased use of glyphosate. Considering this and the lack of protected areas in the pampas, pajonal remnants have recently been highlighted as valuable areas for the conservation of the Rio de la Plata Grasslands (Bilenca and Miñarro 2004). The causes of fragmentation, the area of pajonal fragments, their size and shape, the distance among patches, and the existence of ecological barriers and contact zones must be known in order to set conservation and management strategies in these environments (Forman 1995).

We hypothesize that the percentage of agriculture (annual crops and sown pastures) is a main indirect driving factor affecting the size and spatial configuration of remaining pajonal patches, which directly result from a positive selection of large and connected pajonal patches to be put to use for crop production. Small and isolated pajonal patches are less preferred by farmers for replacement, because of increased costs of machinery movement between suitable patches. Alternatively, the influence of agriculture cover on the configuration of pajonal landscapes can vary in space according to factors that are expressed at a larger scale (edaphic domain): the relative aptitude of soils determines a contrast in the size and isolation of pajonal patch remnants, conditioning production systems and land-use patterns inside each edaphic domain. This study had the following objectives: 1) to determine the current (1998-2000) cover of pajonal grasslands within the former distribution area defined by Vervoorst during 19561960 ; 2) to describe landscape transformation patterns at two spatial scales: a) two edaphic domains which differ in their aptitude for agriculture, and b) ten 22500-ha randomly selected areas (landscapes) within each edaphic domain; and 3) to compare the major changes in pajonal grassland cover between Vervoorst's map and current years.

\section{METHODS}

\section{Study Area}

The study area corresponds to a wide fringe of approximately 2173600 ha extending from northwest to southeast in the

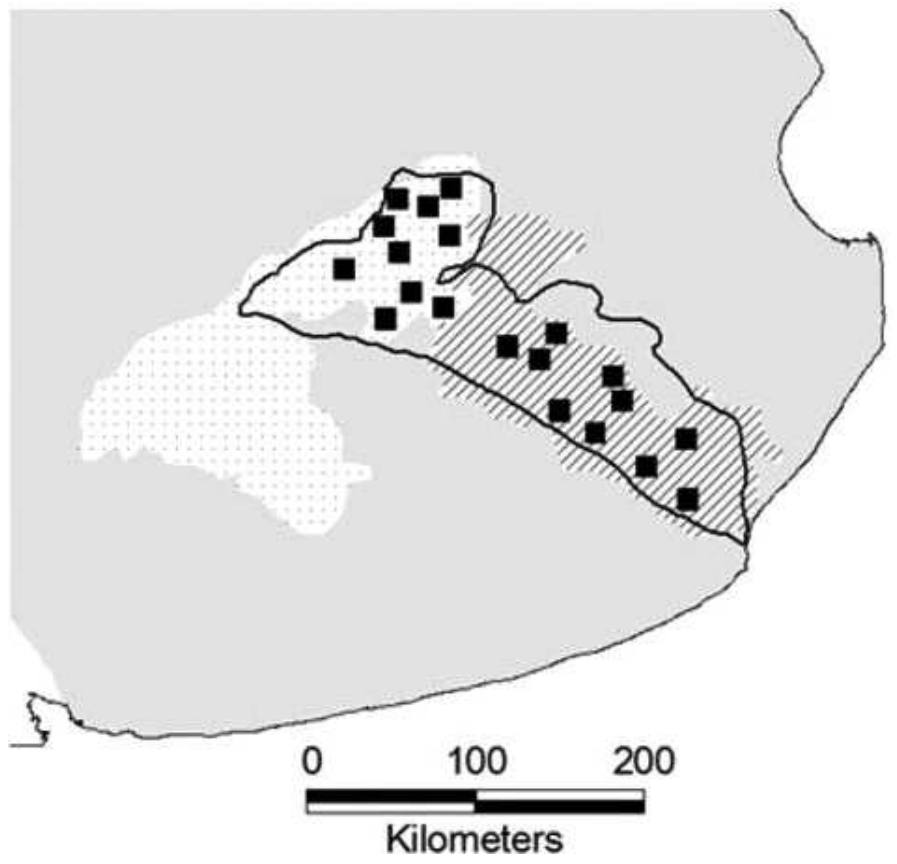

Figure 2. Distribution of the 22500 -ha landscape units (black squares) within the study area (black line), represented in the two studied edaphic domains: low-restriction edaphic domain (LRD, hatched area) and highrestriction edaphic domain (HRD, stippled area).

middle south of the Flooding Pampa subregion, where the pajonal grassland is arranged as a complex mosaic with short grassland communities (Fig. 1). The mentioned fringe includes two areas with different pajonal grassland density: an area of 1400000 ha where the pajonal dominates, and an area where short grasslands dominate and the pajonal appears as a minor component (Vervoorst 1967; Fig. 1). Short grasslands present mainly three floristic variants: humid grassland (characterized by Leersia hexandra, Mentha pullegium, and Solanum malacoxylon, among many others), halophytic steppes (dominated by Distichlis spicata), and flechillar community (dominated by species of the genera Stipa spp. Piptochaetium spp., among others; Vervoorst 1967; Burkart et al. 1990; León 1991).

The climate is humid and temperate, with mean annual precipitation of $1000 \mathrm{~mm}$, mean annual temperature of $14^{\circ} \mathrm{C}$, mean minimum temperature of $6.8^{\circ} \mathrm{C}$ in July and mean maximum temperature of $21.8^{\circ} \mathrm{C}$ in January (Soriano et al. 1991).

The parental material of the soils corresponds to very fine sandy silts of aeolian origin (loess), deposited during more arid climates through the Late Pleistocene and Holocene. Soil types are mainly Natraquols and Natraqualfs developed on clayed silts reworked by floods. The study area almost completely includes two edaphic domains of the Buenos Aires Province that differ in soil constraint for tillage and crop growth (Fig. 2). The low-restriction domain (edaphic domain 22 in INTA y SAGPyA 1989, hereafter LRD) consists of a 1268-ha mosaic of typical Natracuol soils that occupy the depressed planar areas subjected to frequent floodings, Hapludol Thapto Natric soils that are located in the microreliefs of the hills, and typical Natralbol soils located in the deflation lunettes. The natric horizon acts like an impediment for water circulation and the development of roots, controlling the hydric regime of the ground and its productivity (Godz et al. 1994). The high- 
restriction domain (edaphic domain 23, hereafter HRD) presents Natraquols and Natraqualfs developed on clays reworked by floodings. The calcareous restricting soil layer in the HRD is thicker and shallower (between 50 and $100 \mathrm{~cm}$ deep) than in the LRD, so low permeability and poor superficial drainage determines higher flooding incidence in the HRD than in the LRD (INTA y SAGPyA 1989). Therefore, the occurrence of HRD soils reduces crop growth and yield, so these areas were generally avoided for agriculture.

\section{Satellite Image Information and Image Processing}

For mapping the distribution area of the pajonal, the following three images were used: 1) Landsat Thematic Mapper (TM) image acquired on 26 August 1998 (Path and Roth 224/86), and 2) two Landsat Enhanced Thematic Mapper Plus (ETM+) images acquired on 29 September 2000 (Path and Roth 225/85 and 225/86). Images were acquired within such a wide period of time because the frequent floods and cloudy conditions that affect the region made it impossible to get adequate winter scenes for the entire mapped area at the same time. Winter images were selected because Paspalum spp. present a maximum percentage of standing dead tissue in that season, and its spectral signature can be distinguished from the spectral signature of short grasslands composed of both warm- and cold-season species (Herrera et al. 2005).

The images were geometrically registered (first-order polynomial) with the use of ground control points from topographic maps (Mather 1999). Well-defined features in the images, such as road intersections, corners of paddocks, bends in rivers, roads, and boundaries of cities were chosen as ground control points. The base image used was the Traverse Mercator Projection (Gauss Krugger) with an International Ellipsoid (1909). The root-mean-square error of the registration process was approximately 0.205 pixels. All images were preprocessed by converting the Landsat TM/ETM+ digital numbers to top-of-atmosphere reflectance units as specified in the Landsat 7 Science Data User's Handbook (National Aeronautics and Space Administration 1998). Software employed was Erdas Imagine 9.1 (Leica Geosystems Geospatial Imaging, LLC, Norcross, GA).

\section{Ground Information}

A total of 380 ground points were registered across the study area during 1997, 2001, 2002, 2003, and 2004, with the use of a global positioning system with a mean error of $5 \mathrm{~m}$. Points were preferentially located beside principal routes and internal roads to assure accessibility. Logistical and economic considerations did not permit acquiring ground samples randomly; however, we consider that their great number and wide distribution throughout the study area minimized sampling biases. Control points were selected within relatively homogeneous landscape units greater than 1 ha and were classified into the following ecosystem types: annual crops (mainly Triticum aestivum and Avena sativa and plowed fields or warm-crop stubble), sown pastures (mainly Agropyron elongatum and Festuca arundinacea), short grassland (seminatural grassland used for grazing or successional stages from old crops or old pastures), pajonal (grassland stands partially or completely dominated by Paspalum spp., generally describing a two-phased mosaic of Paspalum spp. patches over short grasslands), wetlands (clean or turbid bodies of water), and anthropogenic areas (farmhouses and small patches of planted trees). The 380 points were arbitrarily split into two groups: 75 points were used as training sites (used to optimize classification parameters) and 305 points were used as control sites (used to assess the accuracy of the final classification) distributed in the categories as follows: 23 crops, 10 sown pastures, 97 short grassland, 159 pajonal, eight wetlands, and eight anthropogenic areas.

As ground information was obtained in different years (1997, 2001, 2002, 2003, and 2004) from satellite images (1998 and 2000), the spectral signs of the pajonal and other landscape units were studied with the help of both sets of data. In addition, satellite images were obtained in winter but field visits were performed in different periods of the year to improve the spectral signs of the studied categories.

\section{Classification of the Images}

Unsupervised classification was accomplished with the use of the chain algorithm or ISODATA with 50 clusters, which were then manually combined into the six land-use categories already mentioned (Herrera et al. 2005). The classification was performed with Erdas Imagine 9.1 and the following four Landsat bands: TM3, TM4, TM5, and TM7. The spectral signature for each land-cover class was defined by the mean pixel response and the standard deviation of each band within each training area. A $3 \times 3$ median filter was employed to remove isolated pixels.

\section{Accuracy Assessment}

The accuracy of the classification map was assessed with the use of the error matrix (Congalton 1991, 2001) from which was derived the overall accuracy, the user's and the producer's accuracies, and the Kappa statistic (also called KHAT or Kappa index of agreement [KIA]; Chuvieco 1990; Congalton 1991). The producer's accuracy is the probability of a reference pixel being correctly classified, whereas user's accuracy is the probability that a pixel classified on the map actually represents that category on the ground (Jensen 2005). The Kappa statistic is an alternative measure of the overall classification accuracy that subtracts the effect of chance agreement and quantifies how much better a particular classification is, as compared to a random classification (Congalton and Green 1999).

We used the $Z$ test for Kappa statistic to test whether the results presented in the error matrix are significantly better than a random result (the null hypothesis: Kappa statistic $=0$ ). The $Z$ test is based on the standard normal deviate and the fact that, although remotely sensed data are discrete, the Kappa statistic is asymptotic normally distributed. We performed the test in SAS version 8.02 (Anonymous 2001).

Global accuracy was evaluated with the use of the 305 points previously mentioned. In the ground, each point was five pixels $(150 \mathrm{~m})$ away from the edge of the route or road to eliminate edge effects. Training/verification sites were defined by a set of $3 \times 3$ pixels around each control point. The cover class that best represented the vegetation within the $8100-\mathrm{m}^{2}(3 \times 3$ pixel set) area was assigned to each site, except for the intrinsically heterogeneous pajonal-short grassland mosaics where the occurrence of the pajonal class in one pixel $\left(900 \mathrm{~m}^{2}\right)$ within a pixel set was enough to classify it as pajonal. 


\section{Spatial Analysis}

Landscape patterns were quantified for the two main sectors of the study area (LRD and HRD). Inside each sector and within the area of distribution of pajonal landscape according to Vervoorst (1967), 10 subsets (hereafter windows) of $15 \times$ $15 \mathrm{~km}$ (22 $500 \mathrm{ha}$, each one considered a landscape) were randomly delimited and each one was analyzed with the raster version of FRAGSTATS 3.1 (McGarigal and Marks 1995; Fig. 2).

FRAGSTATS calculates a number of spatial metrics for each patch, for each cover class, and for the entire landscape. In this study seven metrics were analyzed; most of them were calculated only for the pajonal class, whereas others were calculated also for the different land-use types (crops, sown pastures, and short grasslands): 1) percentage of landscape (\%LAND) occupied by each land cover type; 2 ) patch number (PN) of pajonal class; 3) largest patch index (LPI), or percentage of the landscape comprised by the larger pajonal patch $(0-100 \%)$; 4) mean patch size (MPS) of pajonal class ( $>0$, without limit); 5) patch-size coefficient of variation (PSCV, standard deviation/mean, \%) of pajonal class; 6) landscape shape index (LSI), or the irregularity of pajonal patch shape; this index measures the perimeter-to-area ratio for the landscape as a whole (in this work it quantifies the amount of edge of pajonal patches present in a landscape relative to what should be present in a landscape of the same size but with simple geometric shape [square]); and 7) Euclidean nearestneighbor distance (ENND), which measures the distance from pajonal patches to the closest patch of the same type. It is the simplest measure of distance between patches commonly used in isolation studies.

These metrics were chosen because they quantify fundamental aspects of landscape composition and configuration (McGarigal and Marks 1995) and have been shown to be useful descriptors of landscape structure in different landscape types (Riitters et al. 1995; Cushman and Wallin 2000). Furthermore, these metrics do not include redundant metrics (i.e., representing the same information in an alternative way). The PN of a particular ecosystem might indicate that the ecosystem suffers a high rate of disturbance (e.g., deforestation). Nevertheless, information on the number of patches alone does not have any interpretive value because it has no information about area, distribution, or shape of the patches (McGarigal and Marks 1995). For this reason, PN was calculated with other metrics that could together be more interpretable. Progressive reduction in the size of ecosystem fragments is a key component of ecosystem fragmentation; thus a landscape with a smaller MPS than another landscape might be considered more fragmented (McGarigal and Marks 1995). In a similar way, the higher the ENND is, the higher the fragmentation of an ecosystem type, because the distance from one patch to another might be increasing due to human disturbances (e.g., deforestation, land-use change, etc.). LSI reflects the shape and complexity of the patches. Higher index values indicate higher fragmentation, which is due to disturbances on the edges of an ecosystem (McGarigal and Marks 1995).

At edaphic-domain scale, patterns of landscape fragmentation of pajonal class were compared between edaphic domains with the use of a mean-comparison Student's $t$ test (Statistica
1998). At landscape scale, the relationship between percentage of agriculture (annual crops and sown pastures) with area and isolation of pajonal patches were analyzed with regression models. The variation of the mean size of pajonal patches with the percentage of agriculture was adjusted to a nonlinear model. Data on patch isolation were log transformed to approximate normality.

\section{Pajonal Extent and Distribution: Past and Present}

The 1998-2000 cover map obtained by spectral classification from remote-sensing data with six classes was reclassified to a map with two broad cover types (pajonal and nonpajonal). The obtained map was compared with the former map described by Vervoorst (1967) from a 4-yr-long terrestrial survey (19561960). There is no information about the accuracy of Vervoorst's map. In order to facilitate map comparison the following procedure was made: The 1998-2000 map was smoothed by applying a despeckle filter with the use of Adobe Photoshop CS with a 40-pixel radius selected arbitrarily. The despeckle filter detects the edges in a layer (areas where significant color changes occur) and blurs all of the selection except those edges. This blurring removes noise while preserving detail. In this way a coarse-grain map version of the 1998-2000 map was obtained that was comparable to the 1956-1960 map obtained by Vervoorst (1967).

The number of pixels belonging to the presence and absence of pajonal class was compared between both maps at the edaphic-domain scale through a cross-tabulation procedure. This allowed for the accounting of pajonal areas that have remained as pajonal and areas that were converted to other cover classes during the revised period.

\section{RESULTS AND DISCUSSION}

\section{Classification Accuracy}

A very good overall accuracy $(78.03 \%)$ was obtained for image classification. The Kappa value was 0.64 , and the accuracy of the unsupervised classification was significantly better than chance. The pajonal class was very well discriminated from other landscape units, with $88.68 \%$ of the pixel sets correctly classified (producer's accuracy); $8.81 \%$ of the pixel sets of the pajonal class were classified as short grassland, $1.88 \%$ as crops, and $0.62 \%$ as sown pastures $(11 \%$ of pajonal pixel sets were incorrectly classified). Furthermore, $18.54 \%$ of the pixel sets of the short-grassland class, $1.68 \%$ of the pixel sets of the sownpasture class, and $0.56 \%$ of the pixel sets of crop class were calculated as pajonal $(21 \%$ of pajonal pixel sets were incorrectly classified; Table 1).

Several problems are inherent in grassland classification. The first is the nature of grasses in the strict sense. Individual grasses are much smaller than trees and shrubs and their size is below the resolution ability of any digital system commonly used, such as Landsat images. In addition, there is a spatial variation in the coverage within a determined grassland type. Unlike crops, grasslands are rarely homogeneous. Each type of grassland may consist of a mixture of small pools, bare ground, and patches of grasses, forbs and/or shrubs; thus forming an environment where pure "pixels" are rare, and where considerable spectral heterogeneity can be found within the 
Table 1. Error matrix for the unsupervised classification. The diagonal contains correctly classified test sites. ${ }^{1}$

\begin{tabular}{|c|c|c|c|c|c|c|c|c|}
\hline \multirow[b]{2}{*}{ Classified data } & \multicolumn{8}{|c|}{ Reference data } \\
\hline & Crops & $\begin{array}{c}\text { Sown } \\
\text { pastures }\end{array}$ & $\begin{array}{c}\text { Short } \\
\text { grassland }\end{array}$ & Pajonal & Wetlands & $\begin{array}{c}\text { Anthropogenic } \\
\text { areas }\end{array}$ & Total & $\begin{array}{l}\% \text { user's } \\
\text { accuracy }\end{array}$ \\
\hline Crops & 20 & 0 & 3 & 3 & 0 & 0 & 26 & 76.9 \\
\hline Sown pastures & 0 & 5 & 3 & 1 & 0 & 0 & 9 & 55.55 \\
\hline Short grassland & 2 & 2 & 56 & 14 & 0 & 0 & 74 & 75.67 \\
\hline Pajonal & 1 & 3 & 33 & 141 & 0 & 0 & 178 & 79.21 \\
\hline Wetlands & 0 & 0 & 2 & 0 & 8 & 0 & 10 & 80 \\
\hline Anthropogenic areas & 0 & 0 & 0 & 0 & 0 & 8 & 8 & 100 \\
\hline Total & 23 & 10 & 97 & 159 & 8 & 8 & 305 & - \\
\hline$\%$ producer's accuracy & 86.96 & 50 & 57.7 & 88.68 & 100 & 100 & - & - \\
\hline
\end{tabular}

${ }^{1}$ Overall accuracy: $238 / 305=78.03 \%$; Kappa statistic ( \pm standard error): $0.64 \pm 0.04$.

same paddock (Vitoria-Gasteiz Mueller and Hoffer 1997). Despite this, the unsupervised classification allowed us to obtain very good producer and user accuracies for the pajonal class, discriminating it from other landscape covers. However, it is important to note that there was a certain degree of confusion between pajonal and short grassland classes, mainly due to the above-mentioned sources of spatial complexity of the grassland communities, and because the pajonal is not a pure category, but a mosaic of tall and short grasslands.

\section{Landscape Composition and Pajonal Remnants}

For the current period (1998-2000), total area covered by pajonal was estimated in 693388 ha $(32.5 \%$ of the study area). Pajonal replacement is mainly explained by the expansion of short grasslands, whereas smaller portions corresponded to sown pastures and crop fields (Table 2; Fig. 3), this pattern is repeated in each edaphic domain (Table 2). Relative cover of short grassland in both edaphic domains was similar, whereas the relative cover of crops and sown pastures was greater in the LRD (Table 2).

The described pattern is associated with the progressive historical replacement that has eliminated the pajonal in the major part of the pampas, with replacement rates that were obviously more important in subregions with less edaphic restrictions, and where the study area represents the last scene of this process. In contrast with other regions of the pampas, where native grasslands were completely replaced by croplands (Soriano et al. 1991), pajonal replacement in the Flooding Pampa is better explained by the expansion of short grasslands

Table 2. Coverage (\%) by the different land-use types resulting from unsupervised classifications for the total map and for each edaphic domain. Low-restriction edaphic domain (LRD) and high-restriction edaphic domain (HRD) vary in the depth and thickness of a calcareous soil layer.

\begin{tabular}{lccc}
\hline \multicolumn{1}{c}{ Category } & Total cover (\%) & LRD (\%) & HRD (\%) \\
\hline Crops & 10.69 & 12.1 & 8.7 \\
Sown pastures & 5.94 & 7.1 & 4.3 \\
Short grassland & 46.56 & 46.2 & 47.2 \\
Pajonal & 32.5 & 30.5 & 35.2 \\
Wetlands & 1.94 & 2.48 & 1.12 \\
Anthropogenic areas & 2.37 & 1.78 & 3.22 \\
\hline
\end{tabular}

(Table 2). This is because in this region croplands are restricted to scattered paleodunes (Martínez et al. 2001), and pajonal remnants are mostly associated with nonarable soils (Herrera et al. 2002). In addition, part of the area currently covered by short grassland could be subjected in the past to several fire and crop cycles that removed the pajonal and then gave way to that alternative stable state (Laterra et al. 1998). In addition, it is clear that although the main ecosystem replacing the pajonal is the short grassland, the difference in the area occupied by pajonal between the LRD and the HRD is also related (although to a lesser extent) to an increase in areas destined to crops and sown pastures in the less-restrictive edaphic domain.

\section{Landscape Fragmentation Analysis}

Edaphic Domain Scale. There were significant differences in some spatial patterns of grassland fragmentation between both edaphic domains. Number of pajonal patches $(\mathrm{PN})$ was greater in the LRD than in the HRD $(t=2.51, P=0.022$; Fig. $4 a)$. The largest pajonal patch index (LPI) was higher in the HRD three times more than in the $\operatorname{LRD}(t=-2.18, P=0.044$; Fig. $4 b)$. However, the HRD presented greater variability in LPI, which

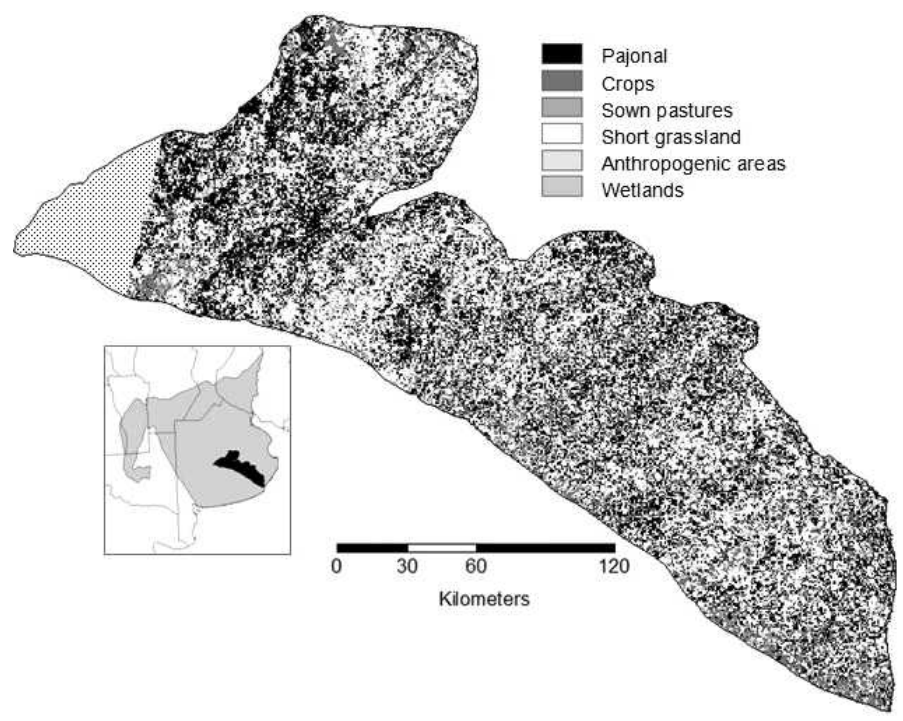

Figure 3. Vegetation map derived from unsupervised classification aggregated into six land-cover classes. Stippled area was not covered by Landsat Thematic Mapper/Enhanced Thematic Mapper Plus images. 

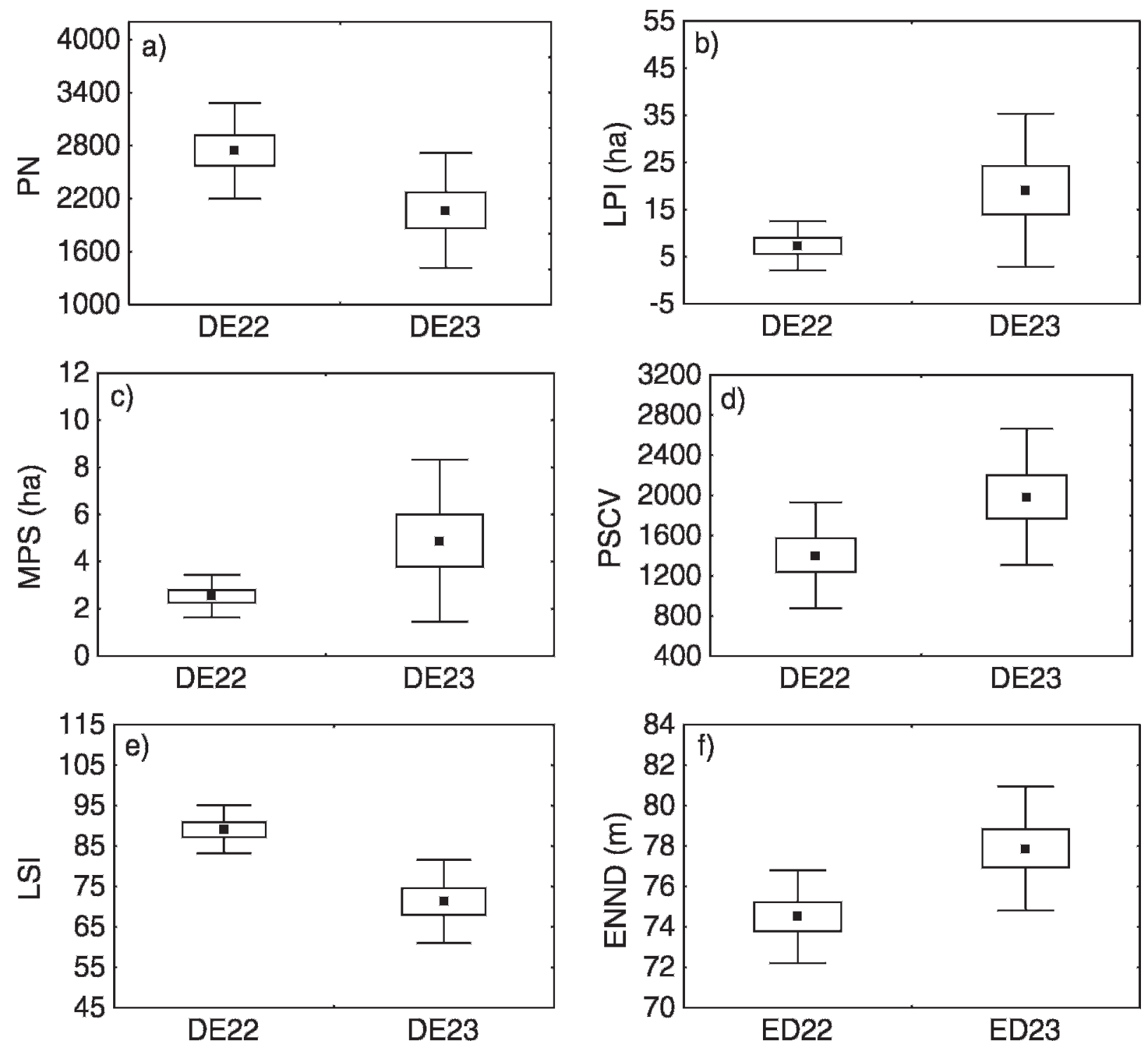

Figure 4. Landscape indexes for pajonal class calculated for low-restriction edaphic domain and high-restriction edaphic domain. PN indicates number of patches; LPI, largest patch index; MPS, mean patch size; PSCV, patch-size coefficient of variation; LSI, landscape shape index; ENND, Euclidean nearest-neighbor distance. Points indicate the mean; boxes, one standard error; lines, the standard deviation.

ranked from 2199.4 ha $(4.3 \%$ of the window with the smaller largest pajonal patch size) to 10011.94 ha $(44.5 \%$ of the window with the higher largest pajonal patch size), whereas the variability for the same variables in the LRD ranked from 1347.6 ha $(0.98 \%$ of the window with the smaller largest pajonal patch size) to 4005.4 ha $(17.29 \%$ of the window with the higher largest pajonal patch size). The mean pajonal patch size (MPS) did not differ between edaphic domains $(t=1.67$, $P=0.11$; Fig. 4c).

According to the PSCV, results showed higher heterogeneity in the mean area of patch size in the HRD $(t=-2.14$, $P=0.045$; Fig. $4 \mathrm{~d}$ ). The most irregular pajonal patches (LSI) appear in the LRD $(t=4.73, P<0.001$; Fig. $4 \mathrm{e})$. The ENND between pajonal patches also differed between edaphic domains, being greater in the HRD $(t=-2.79, P=0.012$; Fig. 4f).

Although there are no quantitative data of pajonal grassland patterns at landscape scale since presettlement times, it becomes clear that the actual pajonal ecosystem is highly fragmented. The fragmentation pattern differed between edaphic domains, being higher in the LRD, which presented an increase in number of pajonal patches, accompanied by a decrease in the total patch area, the mean patch size, patch-size variability, and patch irregularity (Fig. 4). These results coincide with descriptions made by several authors such as Godron and Forman (1983) and Krumel et al. (1987), who predicted that in a landscape with higher management, the number of patches would increase, but their sizes would diminish.

The pajonal in the HRD presents a lower degree of fragmentation and consequently a better status for conservation, presumably because edaphic conditions (characterized by a calcareous layer at few centimeters of depth) limited the use of plows and the consequent pajonal elimination. The above affirmation is related to a greater mean patch size and a larger pajonal patch index (a metric of considerable conservation 

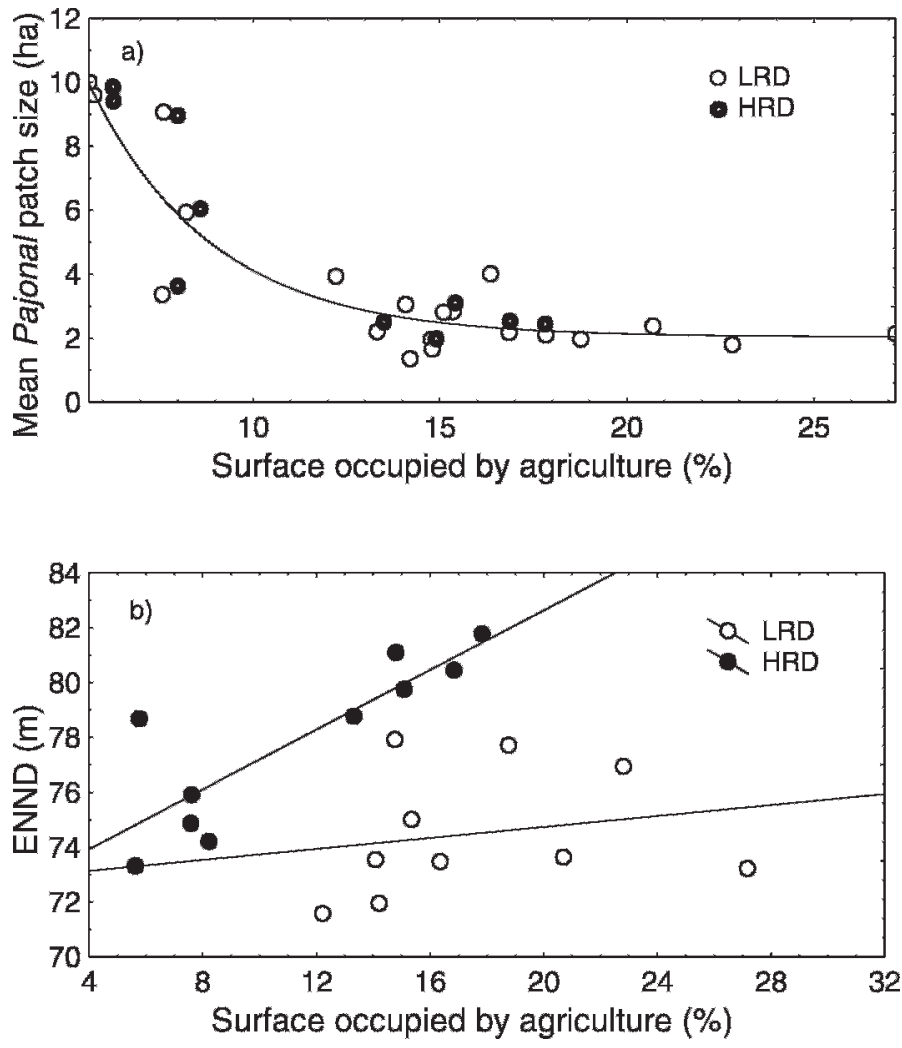

Figure 5. Relationship between mean size of pajonal patches (a) and Euclidean nearest neighbor distance (ENND; b) with the percentage of agriculture (annual crops and sown pastures) at landscape scale. LRD indicates low-restriction edaphic domain; HRD, high-restriction edaphic domain.

value) in the HRD. However, this edaphic domain also showed a great variability in patch size and a great degree of patch isolation, which is mainly due to the presence of greater homogeneous patches that have not been fragmented yet.

Landscape Scale. Agriculture expansion not only means a net loss of pajonal cover, but also a negative change in the spatial integrity of their remnant patches. Significant relationships between different descriptors of spatial integrity of landscape (area and isolation) and percentage of agriculture were found, allowing for a practical valuation and comparison of the conservation value based on nonspatial data basis. Mean size of pajonal patches of overall data (LRD and HRD) asymptotically decreased with the percentage of agriculture $\left(R^{2}=0.832\right.$; Fig. 5a), and a threshold for the strong reduction in this index was detected at approximately $10 \%$ of the surface occupied by agriculture.

The HRD presented a positive relationship between pajonal ENND with the percentage of agriculture $(F=15.88$, $P=0.040, R^{2}=0.66$; Fig. 5a), whereas in the LRD isolation of pajonal patches did not differ with surface occupied by agriculture $(P>0.05$; Fig. $5 b)$. This can be explained by the fact that in the LRD the process of fragmentation has been more intensive, so landscape among windows is relatively more uniform than in the HRD, where larger and more continuous pajonal patches still persist in some areas.

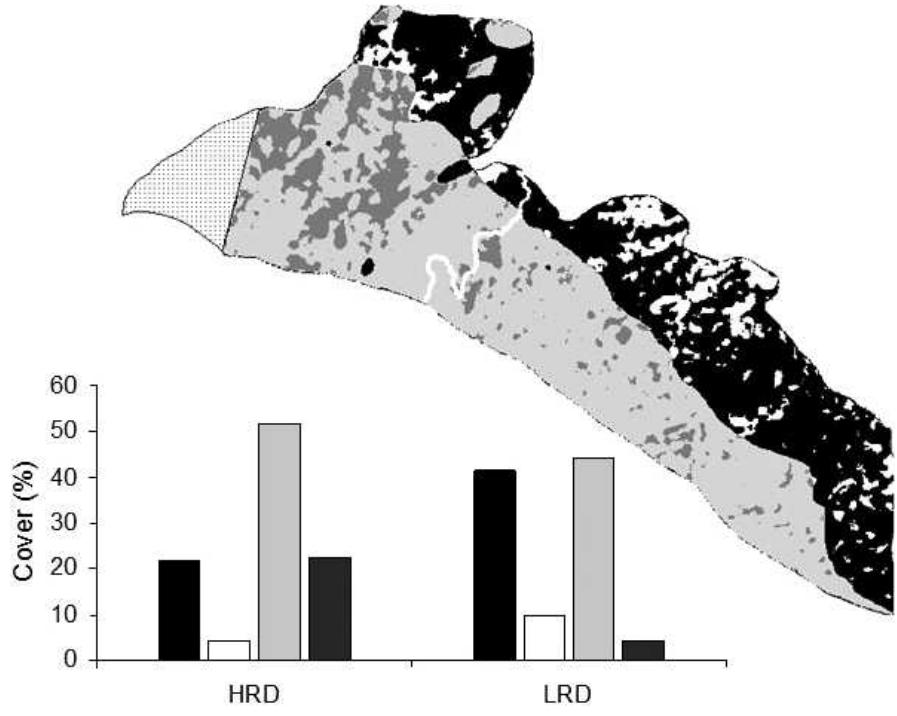

- NoP1956-1960/NoP1998-2000 №P1956-1960/withP1998-2000 口WithP1956-1960/NoP1998-2000 —WithP1956-1960/WithP1998-2000

Figure 6. Changes in pajonal abundance and distribution. NoP indicates area without pajonal; WithP, area with pajonal. Vervoorst (1967) surveyed land cover during 1956-1960 and classification data during 1998-2000 was from Fig. 3. White line inside the map represents the limit between high-restriction edaphic domain (HRD) and lowrestriction edaphic domain (LRD). Stippled area was not covered by Landsat Thematic Mapper/Enhanced Thematic Mapper Plus images.

\section{Pajonal Extent and Distribution: Past and Present}

The $52 \%$ in the LRD and the $44 \%$ in the HRD of area with pajonal in 1956-1960 disappeared in 1998-2000. In the LRD $10 \%$ of the area occupied by pajonal in 1956-1960 was maintained in 1998-2000, while in the HRD the unchanged area was three times more. On the other hand, in the LRD almost $10 \%$ of the surface without pajonal in 1954-1960 appears with pajonal in 1998-2000, whereas in the HRD this change was almost half (Fig. 6).

Abundance of pajonal communities has surprisingly not declined since the times when the first vegetation map was carried out (Vervoorst 1967). The most surprising result obtained from map comparisons is the widespread increase of the pajonal in areas where the short grassland dominates, according to Vervoorst (1967). This result disagrees with a state and transition model of pajonal dynamics, which assumes that short grassland is not usually replaced by pajonal, because fire is rare in the usually overgrazed short grassland; Paspalum spp. can only successfully establish from seeds on sites strongly disturbed by fire and their seeds have a poor dispersal capacity both in time and space (Laterra et al. 1998). Because model predictions are mostly based on short-term observations of population biology of dominant species in relation to frequent disturbance sources (grazing, fire, and cropping), the disagreement between the predicted and observed replacement of short grassland by the pajonal community in part of the study area is probably reflective of the model's inability to capture relevant processes and mechanisms that may influence pajonal dynamics in the long term. The substitution process described in this work still continues in the pampas, and especially affects marginal areas for agriculture. 


\section{MANAGEMENT IMPLICATIONS}

The identification of underlying causes of the spatial patterns of pajonal fragmentation generated in this study represents an important input for developing policies of biodiversity conservation, landscape planning, and sustainable management of these grasslands. Landscape planning and ecosystem conservation in rural areas is particularly important nowadays in Argentina because of the growing pressure of agricultural intensification on natural resources, resulting from global increases in commodity prices and food demand. There is an absence of available fiscal resources for the conservation of these native grasslands; private conservation efforts would benefit from particular attention to landscape attributes that determine fragmentation by agriculture. Policies tending to prevent further fragmentation in soil units where the pajonal is best conserved and promoting the conservation of corridors among big patches will positively contribute to pajonal survival as a distinctive element of the pampas landscape.

\section{ACKNOWLEDGMENTS}

The EEA Balcarce (Instituto Nacional de Tecnología Agropecuaria) provided us with vehicles and laboratories. The Comision Nacional de Actividades Espaciales supplied the satellite data. We thank Lic. Lucía Bernad for reading the manuscript, and two anonymous reviewers for their helpful comments in revising the manuscript.

\section{LITERATURE CITED}

Alonso, S. L., P. Laterra, and F. G. Garita. 1995. Paspalum exaltatum Presl. In: Los pajonales de paja colorada del SE Bonaerense. Proceedings of the 19th Congreso Argentino de Producción Animal, Mar del Plata, Argentina. p. 97-99.

Altesor, A., E. Di Landro, H. May, and E. Ezcurra. 1998. Long-term species change in a Uruguayan grassland. Journal of Vegetation Science 9:173-180.

Altesor, A., M. Oesterheld, E. Leoni, F. Lezama, and C. Rodríguez. 2005. Effect of grazing on community structure and productivity of a Uruguayan grassland. Plant Ecology 179:83-91.

Anonymous. 2001. SAS/STAT software. Release 8.02. Cary, NC, USA: SAS Institute, Inc.

Apan, A. A., S. R. Raine, and M. S. Paterson. 2002. Mapping and analysis of changes in the riparian landscape structure of the Lockyer Valley catchment, Queensland, Australia. Landscape and Urban Planning 59:43-57.

Bilenca, D., and F. Miñarro. 2004. Identificación de áreas valiosas de pastizal (AVPs) en las pampas y campos de Argentina, Uruguay y sur de Brasil. 1st ed. Buenos Aires, Argentina: Fundación Vida Silvestre. 323 p.

Burkart, S. E., R. J. C. León, and C. P. Movia. 1990. Inventario fitosociológico del pastizal de la Depresión del Salado (Prov. Bs. As.) en un área representativa de sus principales ambientes. Darwiniana 30:27-69.

Chuvieco, E. 1990. Fundamentos de teledetección espacial. Madrid, Spain: Rialp, S.A. 453 p.

Congalton, R. G. 1991. A review of assessing the accuracy of classifications of remote sensed data. Remote Sensing and Environment 37:35-46.

Congalton, R. G. 2001. Accuracy assessment and validation of remotely sensed and other spatial information. International Journal of Wildland Fire 10:321328.

Congalton, R. G., and K. Green. 1999. Assessing the accuracy of remotely sensed data: principles and practices. Boca Raton, FL, USA: Lewis Publishers. $137 \mathrm{p}$.

Costanza, R., R. C. d’Arge, R. de Groot, S. Farber, M. Grasso, B. Hannon, K. Limburg, R. V. O’Nelll, J. Paruelo, R. G. Raskin, S. Naeem, P. Sutton, and M. Van Den Belt.
1997. The value of the world's ecosystem services and natural capital. Nature 387:253-260.

Cushman, S. A., And D. 0. Wallin. 2000. Rates and patterns of landscape change in the Central Sikhote-alin Mountains, Russian Far East. Landscape Ecology 15:643-659.

Dirección de Estadísticas Agropecuarias. 2003. Censo Nacional Agropecuario 2000. Available at: htpp://www.mgap.gub/diea/censo2000/censo_general_agropecuario_ 2000.htm. Accessed January 2007.

Eriksson, O., S. A. O. Cousins, and H. H. Bruun. 2002. Land-use history and fragmentation of traditionally managed grasslands in Scandinavia. Journal of Vegetation Science 13:743-748.

Fahrig, L., and G. Merriam. 1994. Conservation of fragmented populations. Conservation Biology 8:50-59.

Forman, R. T. T. 1995. Land mosaics: the ecology of landscapes and regions. New York, NY, USA: Cambridge University Press. 632 p.

Ghersa, C. M., and M. A. Martinez-Ghersa. 1991. Cambios ecológicos en los agrosistemas de la Pampa ondulada. Efectos de la introducción de la soja. Ciencia e Investigación 5:182-188.

Godron, M., and R. T. T. Forman. 1983. Landscape modification and changing ecological characteristics. In: H. A. Mooney and M. Godron [EDS.]. Disturbance and ecosystems. New York, NY, USA: Springer-Verlag. p. 12-28.

Godz, P., J. L. Costa, and R. Gonzales Belo. 1994. Mezcla de horizonte en un natracuol de la Pampa Deprimida. Buenos Aires, Argentina: EEA Balcarce, Instituto Nacional de Tecnología Agropecuaria. Boletín técnico No. 121.

Guerschman, J. P., J. M. Paruelo, and I. C. Burke. 2003a. Land use impacts on the normalized difference vegetation index in temperate Argentina. Ecological Application 13:616-628.

Guerschman, J. P., J. M. Paruelo, C. M. Di Bella, M. C. Giallorenzi, and F. Pacin. 2003b. Land cover classification in the Argentine Pampas using multitemporal Landsat TM data. International Journal of Remote Sensing 24:3381-3402.

Herrera, L. P., V. Gómez Hermida, G. A. Martínez, P. Laterra, and N. O. Maceira. 2005. Remote sensing assessment of Paspalum quadrifarium grasslands in the Flooding Pampa, Argentina. Rangeland Ecology and Management 58:406-412.

Herrera, L. P., G. A. Martínez, V. Gómez Hermida, P. Laterra, and N. O. Maceira. 2002. Natural grassland (Paspaletum) distribution in the Flooding Pampa, Argentina. Proceedings of the 45th Symposium of the International Association for Vegetation Science; 3-8 March 2002. Porto Alegre, Brazil: International Association for Vegetation Science. $215 \mathrm{p}$.

Hoekstra, J. M., T. M. Boucher, T. H. Ricketts, and C. Roberts. 2005. Confronting a biome crisis: global disparities of habitat loss and protection. Ecology Letters 8:23-29.

Instituto Brasileiro de Geografia e Estatística. 1999. Censo Agropecuario de Brasil. Available at: http://www.ibge.gob.br. Accessed January 2007.

Instituto Nacional de Estadística y Censos. 2004. Censo Nacional Agropecuario 2002. Available at: http://www.indec.gob.ar. Accessed January 2007.

[INTA y SAgPya] Instituto Nacional de Estadística y Censos and Secretaria de Agricultura, Ganadería, Pesca y Alimentos. 1989. Mapa de suelos de la Provincia de Buenos Aires a escala 1:500 000. Centro de Investigaciones de Recursos Naturales. Buenos Aires, Argentina: CIRN, Instituto de Evaluación de Tierras. Proyecto PNUD ARG 85/019. 472 p.

Jaurena, M., And M. Rivas. 2005. La pradera natural del palmar de Butia capitata (Arecaceae) de Castillos (Rocha): evolución con distintas alternativas de pastoreo. In: INIA Seminario de actualización técnica en manejo de campo natural. p. 15-20.

Jensen, J. R. 2005. Introductory digital image processing: a remote sensing perspective. 3rd ed. Upper Saddle River, NJ, USA: Prentice-Hall. 526 p.

Kemper, J. A., R. M. Cowling, D. M. Richardson, G. G. Forsyth, and D. McKelly. 2000. Landscape fragmentation in South Coast Renosterveld, South Africa, in relation to rainfall and topography. Austral Ecology 25:179-186.

Krumel, J. R., R. H. Gardner, G. Sugihara, R. V. O'Neill, and P. R. Coleman. 1987. Landscape patterns in a disturbed environment. Oikos 48:321-324.

Laterra, P., 0. R. Vignolio, L. G. Hidalgo, 0. N. Fernández, M. A. Cahuépé, and N. O. Macelra. 1998. Dinámica de pajonales de paja colorada (Paspalum spp.) 
manejados con fuego y pastoreo en la Pampa Deprimida Argentina. Ecotrópicos 11:41-149.

Laterra, P., 0. Vignolio, P. Linares, A. Giaquinta, and N. 0. Macelra. 2003. Cumulative effects of fire on the structure and function of a tussock Pampa grassland. Journal of Vegetation Science 14:43-54.

LEón, R. J. C. 1991. Geographic limits of the region. Geomorphology and geology. Regional subdivisions. Floristic aspects. Description of the vegetation. In: A. Soriano [ED.]. Rio de la Plata grasslands. Amsterdam, Netherlands: Elsevier. p. $380-387$.

Manuel-Navarrete, D., S. Slocombe, and B. Mitchell. 2006. Science for place-based socioecological management: lessons from the Maya forest (Chiapas and Petén). Ecology and Society 11:8.

Martínez, G. A., J. Martínez Arca, Q. H. J. Gwyn, and M. V. Bernasconi. 2001. Combined use of RADARSAT-1 and Landsat TM data for geomorphological applications in lowlands of Buenos Aires Province, Argentina. Canadian Journal of Remote Sensing 27:638-642.

MatheR, P. 1999. Computer processing of remotely sensed image: an introduction. New York, NY, USA: John Wiley and Sons, Inc. 292 p.

McGarigal, K., and B. J. Marks. 1995. FRAGSTATS: spatial pattern analysis program for quantifying landscape structure. Portland, OR, USA: USDA Forest Service, Pacific Northwest Research Station, General Technical Report PNWGTR-351. $122 \mathrm{p}$.

Millennium Ecosystem Assessment. 2005. Ecosystems and human well-being: synthesis. Washington, DC, USA: Island Press. $245 \mathrm{p}$.

Milzot, J. C., D. Risso, and R. Methol. 1987. Relevamiento de pasturas naturales y mejoramientos extensivos en áreas ganaderas del Uruguay. Montevideo, Uruguay: Informe Técnico, Ministerio de Ganadería, Agricultura y Pesca. 195 p.

National Aeronautics and Space Administration. 1998. Landsat 7 Science data user's handbook. Data products. Chapter 11. Available at: http://landsathandbook. gsfc.nasa.gov. Accessed October 2008.

Pallarés, O. R., E. J. Berretta, and G. E. Maraschin. 2005. The South American Campos ecosystem. In: J. Suttie, S. G. Reynolds, and C. Batello [EDS.]. Grasslands of the world. Rome, Italy: FAO. p. 171-219.
Paruelo, J. M., J. P. Guerschman, G. Baldi, and C. M. Di Bella. 2004. La estimación de la superficie agrícola. Antecedentes y una propuesta metodológica. Interciencia 29:421-427.

Paruelo, J. M., and O. E. Sala. 1993. Effect of global change on maize production in the Argentinean Pampas. Climate Research 3:161-167.

Quarín, C. C., and E. P. Lombardo. 1986. Niveles de ploidía y distribución geográfica de Paspalum quadrifarium (Gramineae). Mendeliana 7:101-107.

Riltters, K. H., R. V. O’Nelll, C. T. Hunsaker, J. D. Wickham, D. H. Yankee, S. P. Timmins, K. B. Jones, and B. L. Jackson. 1995. A factor-analysis of landscape pattern and structure metrics. Landscape Ecology 10:2339.

Rush, G. M., AND M. Oesterheld. 1997. Relationship between productivity, and species and functional group diversity in grazed and non-grazed Pampas grassland. Oikos 78:519-526.

Saunders, D. A., R. J. HobBs, and C. R. Margules. 1991. Biological consequences of ecosystem fragmentation: a review. Conservation Biology 5:18-32.

Soriano, A., R. J. C. León, O. E. Sala, R. S. Lavado, V. A. Deregibus, M. A. Cauhépé, 0. A. Scaglia, C. A. Velázquez, and J. H. Lemcoff. 1991. Río de la Plata Grasslands. In: R. T. Coupland [ED.]. Ecosystems of the world. Natural grasslands. Introduction and western hemisphere. New York, NY, USA: Elsevier. p. 367-407.

Statistica [computer program]. 1998. Statistica for Windows. Tulsa, OK, USA: StatSoft, Inc.

Turner, M. G., R. V. O'Neill, R. H. Gardner, and B. T. Milne. 1989. Effects of changing spatial scale on the analysis of landscape pattern. Landscape Ecology 3:153-162.

Vervoorst, F. B. 1967. Las comunidades vegetales de la Depresión del Salado (Provincia de Buenos Aires). La vegetación de la República Argentina. Serie Fitogeográfica 7. Buenos Aires, Argentina: Instituto Nacional de Tecnología Agropecuaria.

Vitoria-Gasteiz Mueller, P. W., and R. N. Hoffer. 1997. Law pass spatial filtering of satellite radar data. Photogrammetic Engineering and Remote Sensing $55: 887-895$. 